\title{
MENUMBUHKAN KARAKTER RASA INGIN TAHU SISWA DALAM PEMBELAJARAN SEJARAH MELALUI MEDIA PUZZLE
}

\author{
Oleh : \\ Millati Silmi dan Yani Kusmarni ${ }^{1}$
}

\begin{abstract}
The title of this research is "Growing up Students' Curiosity Character in Learning History Through Puzzle Media in Class XI MIA 3 SMA Negeri 1 Lembang”. This research was held in Class XI MIA 3 SMA Negeri 1 Lembang. This research was motivated by the low of students' curiosity character in learning history. The purpose of this research is how to grow the students' curiosity in learning history among senior high school student, because most of them have wrong perception about learning history that considered as a boring lesson and only focused on text memorize without get the comprehensive perception related to the historical events. The developed indicators of the curiosity character in this research are the ability to ask questions, ability to answer questions from friends or teachers, ability to find out the information from books and the internet, then to contribute in group activities and class discussions, ability to interpret images in puzzles, and the ability to provide solutions of each questions in student work sheet (LKS). The research method used in this research is a Classroom Action Research (PTK) by Kemmis and Mc Taggart. It consists of several stages, including the planning, implementation, observation and reflection. Based on the results of research, the character of the students' curiosity in learning history has increased. It could be seen from the percentage that indicates students' significant change. The percentage showed the change of students' curiosity character which was not good enough to the good category. It can be a good recommendation for teachers or school to develop the learning process to grow students' curiosity character, so that the learning would be more meaningful.
\end{abstract}

Keywords: Puzzle Learning Media, Students' Curiosity Character

\section{PENDAHULUAN}

Pendidikan merupakan salah satu indikator sebuah negara dikatakan maju dan berkembang, dengan pendidikan pula yang menjadi sebuah tonggak kebangkitan suatu bangsa. Dewasa ini pendidikan di Indonesia terlihat siswa-siswa dituntut untuk menjadi pintar namun tidak diimbangi dengan sikapyang baik, disinilah peran pendidikan karakter diperlukan, untuk membentuk siswa-siswa yang tidak hanya cerdas pengetahuan namun juga cerdas budipekerti. Menurut Kemendikbud dalam Sahlan dan Teguh (2012: 39-40) ada 18 karakter yang perlu dikembangkan oleh siswa yaitu : religius, disiplin,jujur, toleransi, kerja keras, kreatif, mandiri, demokratis, rasa ingin tahu, semangat kebangsaan, cinta tanah air, mengahargai prestasi, bersahabat/komunikatif, cinta damai, gemar membaca, pedulilingkungan,

${ }^{1}$ Penulis merupakan mahasiswa Departemen Pendidikan Sejarah FPIPS UPI dan Yani Kusmarni adalah Pembimbing I. Untuk kepentingan akademik dapat menghubungi penulis melalui $e$-mail millatisilmi@gmail.com atau nomor 081222962178 
peduli sosial, dan tanggung jawab. Pengembangan dari berbagai karakter ini dapat diintegrasikan melalui pembelajaran di setiap mata pelajaran salah satunya adalah pelajaran sejarah. Kedudukan pendidikan karakter sendiri sangat penting dalam pembelajaran sejarah, karena pendidikan karakter merupakan proses internalisasi serta penghayatan nilai-nilai budaya dan karakter bangsa. Salah satu karakter yang perlu dikembangkan oleh siswa dalam pembelajaran sejarah adalah karakter rasa ingin tahu. Dalam proses pembelajaran, siswa diharapkan memiliki rasa ingin tahu yang tinggi. Keingin tahuan siswa terhadap materi yang diajarkan oleh guru atau dipelajarinya sendiri dapat menyebabkan ilmunya jauh lebih banyak dibandingkan siswa yang hanya diam menunggu penjelasan dari guru (Salirawati, 2012).

Berdasarkan pengamatan peneliti di kelas XI MIA 3 SMA Negeri 1 Lembang, rasa ingin tahu yang dimiliki oleh siswa masih rendah hal itu terlihat dari rendahnya minat membaca dan bertanya selama proses pembelajaran berlangsung. Keadaan ini juga didukung oleh cara guru dalam mengajar yang kurang menarik sehingga siswa merasa pelajaran sejarah begitu membosankan. Berdasarkan hasil wawancara pada siswa juga didapatkan hasil bahwa siswa kurang minat terhadap pelajaran sejarah karena banyak hafalan dalam pelajaran sejarah selain itu pula dalam menyampaikan materi guru hanya menggunakan metode ceramah, hal tersebut membuat siswa jenuh. Padahal dengan menumbuhkan karakter rasa ingin tahu, pembelajaran akan lebih bermakna dan bermanfaat bagi siswa untuk kehidupannya.
Melihat dari permasalah tersebut, peneliti kemudian memilih media puzzle sebagai upaya pemecah masalah dari rendahnya karakter rasa ingin tahu siswa. Penggunaan media puzzle dalam pembelajaran tentunya akan lebih menarik minat siswa dalam belajar, selain itu dengan menggunakan media puzzle siswa diajak untuk berpikir kritis untuk memecahkan teka-teki dari puzzle itu sendiri. Puzzle akan membuat siswa jadi antusias dalam belajar, ia akan tergerak untuk mencari tahu maksud dari gambar atau kata yang tersusun dalam puzzle. Jika rasa antusias sudah muncul, maka rasa ingin tahu siswa pun akan mulai tumbuh. Melalui permainan puzzle siswa akan diajak untuk melatih otaknya untuk merekonstruksi sesuatu/informasi yang ia dapatkan dan setelah informasi tersebut ia dapatkan siswa akan teransang untuk menyelidiki lebih lanjut mengenai informasi tersebut. Siswa dapat mencari informasi itu dengan bertanya ataupun dengan membaca. Maka dari itu, permaian puzzle ini dirasa cukup efektif untuk melatih menumbuhkan rasa ingin tahu siswa.

Berdasarkan latar belakang tersebut, maka penelitian ini bertujuan untuk menumbuhkan karakter rasa ingin tahu siswa dalam pembelajaran sejarah melalui media puzzle di kelas XI MIA 3 SMA Negeri 1 Lembang. Adapun tujuan khusus dari penelitian ini adalah, (1) Mendeskripsikan rencana pembelajaran sejarah di kelas XI MIA 3 SMA Negeri 1 Lembang melalui mediapuzzleuntukmenumbuhkankarakter rasa ingin tahu siswa dalam pembelajaran sejarah, (2) Mendeskripsikan pelaksanaan pembelajaran sejarah dikelas XIMIA3 SMA Negeri 1 Lembang melalui media puzzle untuk menumbuhkan karakter rasa ingin 


\section{Millati Silmi \\ MENUMBUHKAN KARAKTER RASA INGIN TAHU SISWA DALAM PEMBELAJARAN SEJARAH \\ MELALUI MEDIA PUZZLE}

tahu siswa dalam pembelajaran sejarah, (3) Memaparkan penumbuhan karakter rasa ingin tahu siswa dalam pembelajaran sejarah di kelas XI MIA 3 SMA Negeri 1 Lembang setelah diterapkannya media puzzle, (4) Mengidentifikasi kendalakendala yang dihadapi guru selama proses pembelajaran sejarah berbasis media puzzle untuk menumbuhkan karakter rasa ingin tahu siswa di kelas XI MIA 3 SMA Negeri 1 Lembang.

Sejarah dalam bahasa Yunani disebut istoria, yang berarti belajar. Jadi, sejarah adalahilmu pengetahuanyang mempelajari segala peristiwa, kejadian yang terjadi pada masa lampau dalam kehidupan manusia. Masa lampau dijadikan tolak ukur untuk masa yang akan datang sehingga sejarah mengandung pelajaran tentang nilai dan moral. Sejarah harus dipelajari oleh siswa karena mata pelajaran ini dapat membangunjiwakebangsaandansemangat juang. Mengembangkan pelajaran sejarah berarti pula mengembangkan cara berpikir siswa. Pada pelajaran sejarah dibutuhkan sikap yang kritis dalam memahami suatu peristiwa karena kebenaran sejarah masih bersifat subjektif.Mengembangkan cara berpikir siswa bahkan lebih jauh dapat menumbuhkan rasa ingin tahu.Menurut Hasan (2008:3) mata pelajaran sejarah berpotensi untuk : (1) Mengembangkan kemampuan berpikir, (2) Mengembangkan rasa ingin tahu, (3) Mengembangkan kemampuan berpikir kreatif, (4) Sikap kepahlawanan dan kepemimpinan, (5) Membangun semangat kebangsaan, (6) Mengembangkan kepedulian social, (7) Mengembangkan kemampuan berkomunikasi, (8) Mengembangkan kemampuan mencari, mengolah dan mengkomunikasikan informasi.
Menurut T. Ramli (Asmani, 2012), pendidikan karakter memiliki esensi dan makna yang sama dengan pendidikan moral dan akhlak. Tujuannya adalah untuk membentuk pribadi anak supaya menjadi manusia yang baik, yaitu warga masyarakat dan negara yang baik. Sedangkan pendapat lain dikemukakan oleh Fakry Gaffar (Dharma Kesuma dkk, 2011:5), menurutnya pendidikan karakter merupakan transformasi nilai-nilai kehidupan untuk ditumbuh kembangkan dalam kepribadian seseorang sehingga menjadi satu dalam perilaku orang itu. Pendidikan karakter secara garis besar merupakan upaya yang dilakukan untuk membentuk karakter atau kepribadian seseorang agar mampu berbuat hal yang baik serta menilai hal yang baik. Adapun fungsi dari pendidikan karakter menurut Narwanti(2011)adalah:1)mengembangkan potensi dasar agar berhati baik, berpikiran baik, dan berperilaku baik; 2) memperkuat dan membangun perilaku bangsa yang multikultural; dan 3) meningkatkan peradaban bangsa yang kompetitif dalam pergaulan dunia.

Menurut Kemdikbud dalam Sahlan dan Teguh (2012:39) rasa ingin tahu adalah sikap dan tindakan yang selalu berupaya untuk mengetahui lebih mendalam dan meluas dari sesuatu yang dipelajarinya, dilihat, dan didengar sedangkan menurut Samani dan Hariyanto (2012:119) rasa ingin tahu merupakan keinginan untuk menyelidiki dan mencari pemahaman terhadap peristiwa alam atau peristiwa sosial yang sedang terjadi. Berdasarkan pengertian tersebut dapat disimpulkan bahwa rasa ingin tahu adalah suatu emosi alami yang ada pada dalam diri manusia yang mana adanya keinginan untuk 
menyelidiki dan mencari tahu lebih dalam mengenai suatu hal yang dipelajarinya. Rasa ingin tahu akan membuat siswa terus menerus mencari tahu mengenai apa yang tidak ia ketahui, dengan mencari tahu siswa akan mendapatkan banyak informasi serta ilmu yang baru dan menambah wawasan yang ia punya.

Media berasal dari bahasa latin dan merupakan bentuk jamak dari kata "medium" yang secara harfiah berarti "perantara" yaitu perantara sumber pesan dengan penerima pesan (Susilana, 2008:6). Menurut Romiszowski (Wibawa, 1991:8), media adalah alat pembawa pesan yang berasal dari suatu sumber pesan (yang dapat orang atau benda) kepada pengirim pesan. Jika disimpulkan, media pembelajaran adalah suatu perantara atau sarana komunikasi yang berisikan sumber pesan dalam pembelajaran dari guru (fasilitator) kepada siswa (pembelajar) untuk merangsang inderanya agar dapat menerima informasi.

Puzzle merupakan sebuah permaianan untuk menyatukan pecahan keping untuk membentuk suatu gambar atau tulisan yang telah ditentukan. Istilah puzzle ini oleh masyarakat Indonesia dikenal sebagai permaianan bongkar pasang. Puzzle sebagai alat untuk permaianan yang mengharuskan kita sebagai pemain menyusun potongan-potongan puzzle (Indriana, 2011:23). Berdasarkan pengertian tersebut dapat disimpulkan bahwa permaianan puzzle adalah sebuah media yang pemainnya harus menyusun atau menyatukan pecahan keping untuk membentuk sebuah gambar atau kata yang telah ditentukan. puzzle merupakan media pembelajaran yang sederhana akan tetapi puzzle memiliki manfaat bagi siswa dalam (http://duniaanakcerdas.com/puzzle-2. html, [online] tgl 4 April 2016) antara lain: (1) Meningkatkan keterampilan kognitif, berkaitan dengan kemampuan anak untuk memecahkan masalah, (2) Meningkatkan kemampuan motorik halus, (3) Meningkatkan keterampilan sosial, berkaitan dengan keterampilan berinteraksi dengan orang lain, (4) Melatih koordinasi mata dan tangan, (5) Melatih logika, (6) Melatih kesabaran, (7) Memperluas pengetahuan.

\section{METODE PENELITIAN}

Penelitian ini dilakukan di SMA Negeri 1 Lembang.Secara khusus penelitian ini dilakukan pada siswa kelas XI MIA 3 . Metode yang digunakan dalam penelitian ini adalah PTK(Penelitian Tindakan Kelas). Dalam penelitian ini peneliti menggunakan model desain Penelitian Tindakan Kelas (PTK) yang dikembangkan oleh Kemmis dan Mc. Taggart. Desain Penelitian Tindakan Kelas ini terdiri dari empat tahap yakni, perencanaan (plan), tindakan (act), observasi (observ), dan refleksi (reflect). Penelitian ini dilaksanakan dalam empat siklus penelitian. Masing-masing siklus terdiri dari beberapa tahapan yaitu (1) perencanaan, (2) tindakan, (3) observasi, dan (4) refleksi. Data yang diambil adalah tentang karakter rasa ingin tahu siswa melalui media puzzle. Alat pengumpul data untuk penelitian ini terdiri dari catatan lapangan, lembar observasi dan lembar wawancarasedangkanteknikpengumpulan datanya menggunakan studi dokumentasi, observasi dan wawancara. Analisis data yang digunakan pada penelitian ini adalah analisis data kualitatif (reduksi data, tampilan data, dan penarikan kesimpulan) dan kuantitatif. Untuk validasi data peneliti menggunakan (1) Audit trail, Penggunaan audit trail menurut Wiriaatmadja 


\section{Millati Silmi \\ MENUMBUHKAN KARAKTER RASA INGIN TAHU SISWA DALAM PEMBELAJARAN SEJARAH \\ MELALUI MEDIA PUZZLE}

(2014:170) dimaksudkan untuk memeriksa kesalahan-kesalahan di dalam metode atau prosedur yang dipakai peneliti dan di dalam mengambil keismpulan. Audit trail memeriksa catatan-catatan yang ditulis oleh peneliti atau pengamat mitra lainnya. (2) Member check, menurut Hopkins (dalam Wiriaatmadja, 2014:168), member check ialah "memeriksa kembali keterangan-keterangan atau informasi data yang diperoleh selama observasi atau wawancara dari narasumber yang relevan dengan PTK". (3) Expert opinion, menurut Wiriaatmadja (2014:171) adalah meminta nasehat dari pakar atau para ahli guna mendapatkan nasihat atau bimbingan. Pakar akan memeriksa semua tahapan kegiatan penelitian dan memberikan arahan atau judgements terhadap masalahmasalah penelitian yang ditemukan

\section{HASIL PENELITIAN DAN PEMBAHASAN}

Pada observasi pra-penelitian yang dilakukan sebanyak tiga kali, didapatkan hasil selama pembelajaran sejarah berlangsung siswa cenderung tidak memperhatikan penjelasan dari guru. Ketika guru memberikan pertanyaan tidak ada yang bisa menjawab begitu pula ketika guru memberikan kesempatan siswa untuk bertanya siswa hanya diam dan tidak ada yang bertanya.Ketika guru menanyakan apakah ada siswa yang sudah membaca materi pelajaran sejarah, kebanyakan siswa menjawab tidak membaca.Hal ini menunjukan bahwa karakter rasa ingin tahu siswa rendah terhadap pelajaran sejarah.

Penelitian menumbuhkan karakter rasa ingin tahu siswa melalui media puzzle ini dilakukan sebanyak empat siklus. Adapun subindikatoryang dinilai adalah menyusun dan menginterpretasikan gambar pada puzzledengan wajahyanggembira, antusias menyusun dan menginterpretasikan gambar pada puzzle dalam waktu yang singkat, menginterpretasikan gambar pada puzzle dengan tepat, berperan aktif dalam diskusi kelompok kecil, antusias dalam mencari atau mengusulkan informasi baik dari sumber internet maupun buku untuk memenuhi informasi di LKS, antusias dalam mengusulkan atau memberikan jawaban terhadap pertanyaan yang ada di LKS, tidak berisik atau bergurau selama proses presentasi berlangsung, menyimak atau mendengarkan presentasi dengan wajah yang serius, antusias dalam menjawabataumenambahkanjawabanatas pertanyaan yang diberikan, antusias dalam mengajukan pertanyaan, mengajukan pertanyaan dengan sungguh-sungguh dan wajah yang serius, dan mampu menimpali, mengomentari, berpendapat mengenai jawaban yang diberikan.

Siklus I dilaksanakan pada tanggal 18 Agustus 2016. Peneliti melakukan perencanaan dengan menyiapkan RPP dan kelalengkapan penelitian sepertiinstrumen penelitian, materi ajar, media dan metode yang digunakan selain itu juga peneliti meminta izin dari dosen pembimbing dan guru mitra untuk melakukan penelitian. Pada tahap pelaksanaan peneliti yang bertindak sebagai guru meminta para siswa untuk membentuk empat kelompok kemudian guru meminta siswa untuk menyusun dan menginterpretasikan gambar pada puzzle yang telah diberikan. Masing-masing kelompok diberikan puzzle yang berbeda. Setelah para siswa menyusun dan menginterpretasikan gambar pada puzzle, guru memberikan LKS kepada setiap kelompok untuk 
dikerjakan. Siswa harus menacari tahu informasi mengenai gambar dari puzzle yang telah disusun dari berbagai sumber seperti dari buku, internet atau wacana
LKS.Siswa juga harus menyelesaikan pertanyaan-pertanyaan yang ada di LKS dengan mendiskusikannya. Berikut adalah hasil observasi pada Siklus I:

Tabel 1.1

Persentase Rasa Ingin Tahu melalui Penerapan Media Puzzle Siklus I

\begin{tabular}{|l|l|l|}
\hline Kriteria & $\begin{array}{c}\text { Jumlah } \\
\text { Perolehan } \\
\text { Individu }\end{array}$ & Persentase \\
\hline Baik & - & - \\
\hline Cukup Baik & 19 & $46,34 \%$ \\
\hline Kurang Baik & 22 & $53,65 \%$ \\
\hline
\end{tabular}

Grafik 1.1

Grafik Rasa Ingin Tahu Siswa melalui Penerapan Media Puzzle

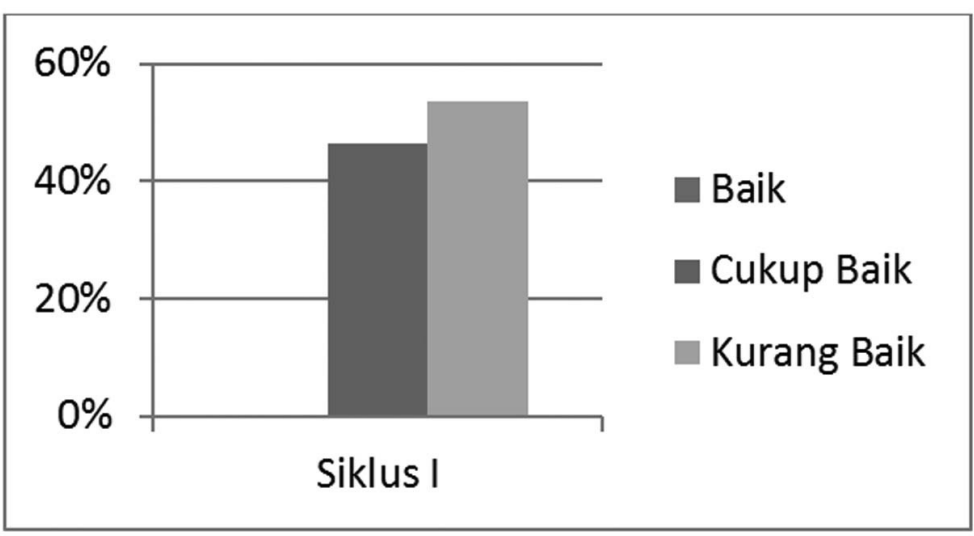

Persentase di atas memperlihatkan secara jelas bahwa karakter rasa ingin tahu siswa dalam pembelajaran sejarah masih rendah. Hal ini berdasarkan pada penilaian dari sub indikator karakter rasa ingin tahu. Pada saat menyusun dan menginterpretasikan puzzle, kebanyakan dari siswa masih terlihat kurang antusias, hal tersebut dapat dilihat dari raut wajah masing-masing siswa yang tidak gembira. Selain itu, kebanyakan dari siswa masih belum mampu untuk menyusun dan menginterpretasikan gambar pada puzzle dalam waktu yang singkat (guru memberikan batas waktu), nampaknya para siswa belum terbiasa untuk menginterpretasikan sesuatu sehingga membutuhkan waktu yang cukup lama. Dalam penginterpretasian gambar pada puzzle pun masih banyak siswa yang kurang tepat dalam memaknai maksud dari gambar yang ada pada puzzle bahkan beberapa siswa nampak belum bisa untuk menginterpreasikannya. 
Ketika dalam diskusi kelompok kecil, masih banyaksiswayang pasifdantidakikut serta dalam proses diskusi. Belum adanya kesadaran untuk ikut aktif dalam proses diskusi karena mereka mengandalkan temannya yang lain untuk mengerjakan tugas yang diberikan oleh guru. Dalam proses diskusi kecil, siswa diminta untuk mencari informasi mengenai tema yang sedang dibahas dari berbagai sumber, pada saat pencarian sumber, siswa tidak terlalu antusias dan cenderung menggunakan internet saja sebagai sumber utama dalam mencari informasi, sumber buku ataupun wacana dalam LKS tidak mereka manfaatkan dengan baik. Pada subindikator terakhir yakni antusias dalam mengusulkan atau memberikan jawaban terhadap pertanyaan yang ada di LKS, sudah ada beberapa siswa yang mampu mengusulkan ataupun memberikan jawabannya untuk pertanyaan yang ada di LKS namun itu hanya sekedarnya saja karena itu merupakan bagian daritanggung jawabnya. Siswa lainnya kebanyakan masih tidak antusias dalam memberikan jawaban karena masih bergantung kepada temannya yang lain. Maka dari itu, peneliti menyimpulkan bahwa rasa ingin tahu siswa dalam pembelajaran sejarah masih rendah.Refleksi yang di dapatkan dari Siklus I ini adalah siswa masih kesulitan untuk menginterpretasikan puzzle, siswa kurang antusias dalam mengusulkan jawaban yang ada di LKS, kerjasama siswa dalam diskusi masih kurang serta siswa masih belum bisa memanajemen waktu dengan baik.

Siklus II dilaksanakan pada tanggal 25 Agustus 2016.Peneliti melakukan perencanaan dengan menyiapkan RPP dan kelalengkapan penelitian seperti instrumen penelitian, materi ajar, media dan metode yang digunakan selain itu juga peneliti meminta izin dari dosen pembimbing dan guru mitra untuk melakukan penelitian. Pada tahap pelaksanaan Siklus II ini adalah presentasi dan diskusi Tanya jawab yang merupakan kelanjutan dari menyusun puzzle dan diskusi kecil Siklus I. Para siswa secara berkelompok mempresentasikan materi tentang penjelajahan bangsa Portugis, Spanyol, Belanda dan Inggris ke Indonesia. Berikut adalah hasil observasi pada Siklus II:

Tabel 1.2

Persentase Karakter Rasa Ingin Tahu melalui Penerapan Media Puzzle

Siklus II

\begin{tabular}{|c|c|c|}
\hline$\underline{\text { Kriteria }}$ & Jumlah Perolehan Individu & Persentase \\
\hline$\underline{\text { Baik }}$ & 3 & $7,31 \%$ \\
\hline Cukup Baik & $\underline{24}$ & $58,53 \%$ \\
\hline Kurang Baik & $\underline{14}$ & $34,14 \%$ \\
\hline
\end{tabular}


Grafik 1.2

Grafik Karakter Rasa Ingin Tahu Siswa melalui Penerapan Media Puzzle

Siklus II

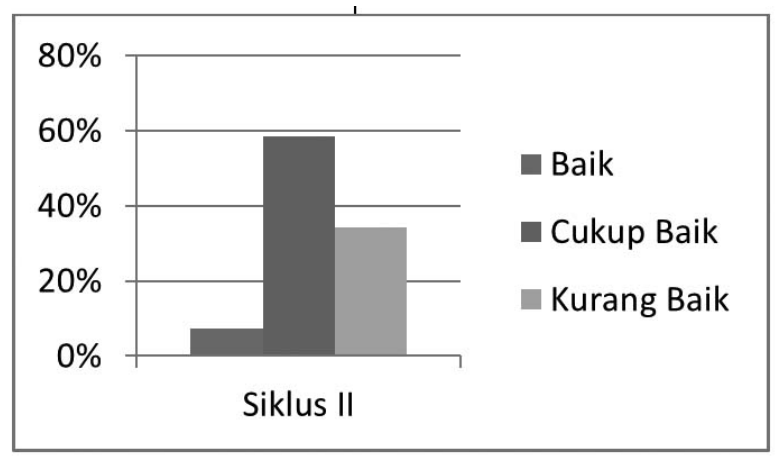

Persentase di atas memperlihatkan bahwa karakter rasa ingin tahu siswa dalam pembelajaran sejarah mulai nampak mengalami peningkatan. Hal ini berdasarkan pada penilaian dari sub indikator karakter rasa ingin tahu. Ketika proses presentasi berlangsung para siswa tidak tertib, berisik, saling bergurau selama proses presentasi berlangsung namun masih dapat dikondisikan dengan baik, mereka kembali fokus dan antusias menyimak serta mendengarkan presentasi dengan namun posisi/gesture tubuh seolah tidak bersungguh-sungguh atau serius mendengarkan. Pada saat proses tanya jawab, sudah mulai ada beberapa siswa yang antusias untuk bertanya, namun lebih banyak siswa yang pasif dalam bertanya. Beberapa pertanyaan yang diajukan masih seputar yang dibahas, jarang ada pertanyaan diluar pembahasan. Dalam menjawab pertanyaan yang telah diberikan, nampaknya beberapa siswa sudah bisa mengemukakan pendapatnya walaupun masih sebatas dorongan dari temannya yang lain, belum ada inisiatif dari diri sendiri.Selanjutnya pada tahap mengomentari atau berpendapat atas jawaban yang telah diberikan, nampaknya para siswa masih enggan untuk memberikan komentarnya.Maka dari itu, peneliti menyimpulkan bahwa rasa ingin tahu siswa dalam pembelajaran sejarah masih kurang namun sudah ada peningkatan.Refleksi yang didapatkan dari Siklus II ini adalah masih banyak siswa yang tidak memperhatikan yang sedang dibahas dalam presentasi, sedikitnya minat siswa untuk bertanya, dan guru kesulitan mengkondisikan siswa yang berisik saat presentasi berlangsung.

Siklus III dilaksanakan pada tanggal 15 September 2016.Peneliti melakukan perencanaan dengan menyiapkan RPP dan kelalengkapan penelitian seperti instrumen penelitian, materi ajar, media dan metode yang digunakan selain itu juga peneliti meminta izin dari dosen pembimbing dan guru mitra untuk melakukan penelitian. Pada tahap pelaksanaan Siklus III ini siswa menyusun dan menginterpretasikan puzzle secara berkelompok dengan tema perlawanan rakyat Indonesia terhadap penjajahan Belanda. Setelah meyusun dan menginterpretasikan puzzle, siswa diminta untuk berdiskusi dan mengerjakan LKS yang telah diberikan oleh guru. Berikut adalah hasil observasi pada Siklus III : 
Millati Silmi

MENUMBUHKAN KARAKTER RASA INGIN TAHU SISWA DALAM PEMBELAJARAN SEJARAH

MELALUI MEDIA PUZZLE

Tabel 1.3

Persentase Karakter Rasa Ingin Tahu melalui Penerapan Media Puzzle

Siklus III

\begin{tabular}{|l|l|l|}
\hline \multicolumn{1}{|c|}{ Kriteria } & $\begin{array}{c}\text { Jumlah Perolehan } \\
\text { Individu }\end{array}$ & \multicolumn{1}{c|}{ Persentase } \\
\hline Baik & 7 & $17,07 \%$ \\
\hline Cukup Baik & 26 & $63,41 \%$ \\
\hline Kurang Baik & 8 & $19,51 \%$ \\
\hline
\end{tabular}

Grafik 1.3

Grafik Karakter Rasa Ingin Tahu Siswa melalui Penerapan Media Puzzle

Siklus III

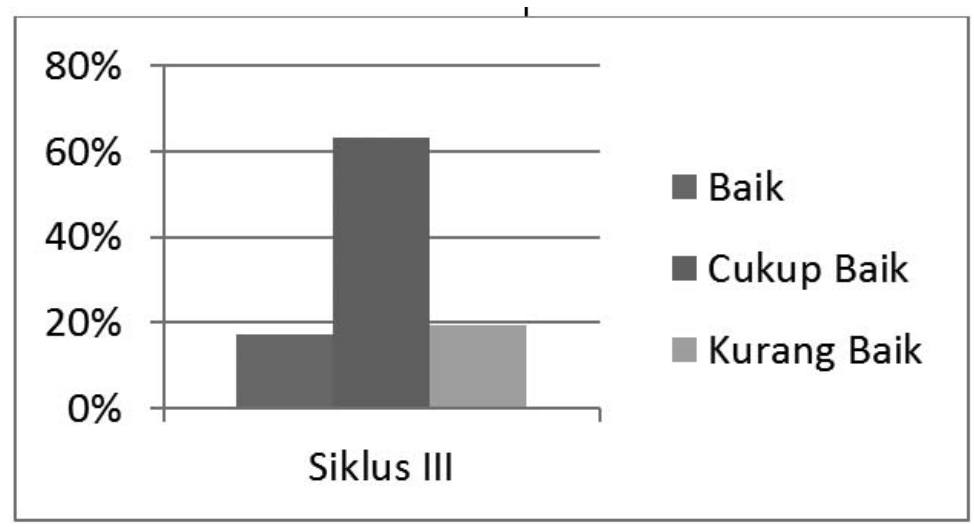

Persentase di atas memperlihatkan bahwa karakter rasa ingin tahu siswa dalam pembelajaran sejarah sudah mengalami peningkatan. Hal ini berdasarkan pada penilaian dari sub indikator karakter rasa ingin tahu. Di lihat dari perbandingan pada siklus sebelumnya khususnya pada Siklus I, pada Siklus III ini persentase dari kategori kurang baik mulai menurun dibandingkan sebelumnya. Pada saat menyusun dan menginterpretasikan puzzle, sudah banyak dari siswa yang terlihat antusias, hal tersebut dapat dilihat dari raut wajah masing-masing siswa yang gembira. Selain itu, siswa sudah mampu untuk menyusun dan menginterpretasikan gambar pada puzzle dalam waktu yang singkat (guru memberikan batas waktu),

nampaknyaparasiswasudahterbiasauntuk menginterpretasikan sesuatu, walaupun pada tahap ini banyak juga siswa yang belum mampu menyelesaikannya dalam waktu yang telah ditentukan, setidaknya sudah ada kemajuan dari pada siklus sebelumnya. Dalam penginterpretasian gambar pada puzzle, sudah ada beberapa siswa yang tepat dalam memaknai maksud dari gambar yang ada pada puzzle, jumlah siswa yang belum bisa untuk menginterpreasikan gambar pada puzzle juga mulai berkurang.

Ketika dalam diskusi kelompok kecil, siswa yang pasif dan tidak ikut serta dalam proses diskusi mulai sedikit jumlahnya. Banyak siswa yang antusias 
dan berkontribusi aktif dalam diskusi. Sepertinya sudah ada kesadaran untuk ikut aktif dalam proses diskusi karena jika mereka mengandalkan temannya yang lain untuk mengerjakan tugas yang diberikan oleh guru mereka tidak akan dapat pengentahuan apa-apa. Dalam proses diskusi kecil, siswa diminta untuk mencari informasi mengenai tema yang sedang dibahas dari berbagai sumber, pada saat pencarian sumber, siswa antusias dalam mencari informasi dari berbagai sumber, mereka sudah mulai memanfaatkan sumber dari buku, wacana dalam LKS dan internet untuk menunjang keingin tahuan mereka. Pada sub-indikator terakhir yakni antusias dalam mengusulkan atau memberikan jawaban terhadap pertanyaan yang ada di LKS, sudah ada beberapa siswa yang aktif dan antusias mengusulkan ataupun memberikan jawabannya untuk pertanyaan yang ada di LKS, namun ada pula yang mengusulkan jawaban hanya sekedarnya saja karena itu merupakan bagian dari tanggung jawabnya.Maka dari itu, peneliti menyimpulkan bahwa karakter rasa ingin tahu siswa dalam pembelajaran sejarah sudah lebih baik dan mengalami peningkatan. Refleksi yang didapatkan dari Siklus III ini adalah masih adanya siswa yang kesulitan dalam menginterpretasikan gambar pada puzzle serta saat menjawab pertanyaan yang ada di LKS masih ada siswa yang mengandalkan temannya untuk menjawab.

Siklus IV dilaksanakan pada tanggal 22 September 2016.Peneliti melakukan perencanaan dengan menyiapkan RPP dan kelalengkapan penelitian seperti instrumen penelitian, materi ajar, media dan metode yang digunakan selain itu juga peneliti meminta izin dari dosen pembimbing dan guru mitra untuk melakukan penelitian. Pada tahap pelaksanaan Siklus IV ini adalah presentasi dan diskusi Tanya jawab yang merupakan kelanjutan dari menyusun puzzle dan diskusi kecil Siklus III. Para siswa secara berkelompok mempresentasikan materi tentang perlawanan rakyat Indonesia melawan penjajah Belanda. Berikut adalah hasil observasi pada Siklus IV:

Tabel 1.4

Persentase Karakter Rasa Ingin Tahu melalui Penerapan Media Puzzle

Siklus IV

\begin{tabular}{|l|l|l|}
\hline \multicolumn{1}{|c|}{ Kriteria } & \multicolumn{1}{|c|}{$\begin{array}{c}\text { Jumlah Perolehan } \\
\text { Individu }\end{array}$} & \multicolumn{1}{c|}{ Persentase } \\
\hline Baik & 14 & $34,14 \%$ \\
\hline Cukup Baik & 27 & $65,85 \%$ \\
\hline Kurang Baik & - & - \\
\hline
\end{tabular}


Millati Silmi

MENUMBUHKAN KARAKTER RASA INGIN TAHU SISWA DALAM PEMBELAJARAN SEJARAH

MELALUI MEDIA PUZZLE

Grafik 1.4

Grafik Karakter Rasa Ingin Tahu Siswa melalui Penerapan Media Puzzle

Siklus IV

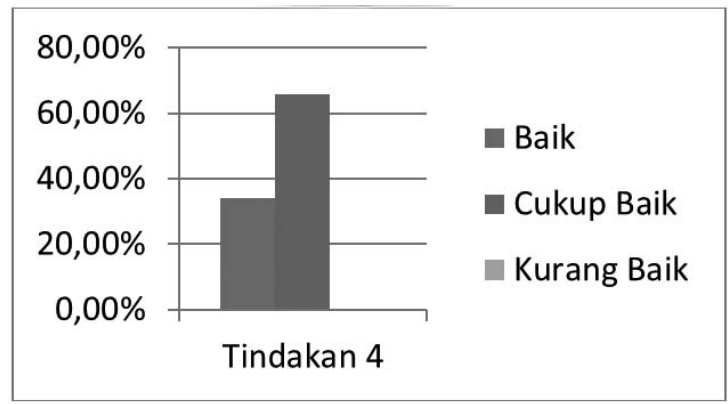

Persentase di atas memperlihatkan secara jelas bahwa karakter rasa ingin tahu siswa dalam pembelajaran sejarah mengalami peningkatan yang baik. Hal ini berdasarkan pada penilaian dari sub indikator karakter rasa ingin tahu. Ketika proses presentasi berlangsung para siswa sudah mulai tertib, tidak berisik ataupun saling bergurau. Para siswa juga mulai antusias menyimak serta mendengarkan presentasi dengan wajah yang serius. Pada saat proses tanya jawab, sudah mulai ada beberapa siswa yang antusias untuk bertanya, namun lebih banyak siswa yang pasif dalam bertanya. Beberapa pertanyaan yang diajukan masih seputar yang dibahas, jarang ada pertanyaan diluar pembahasan.Dalam menjawab pertanyaan yang telah diberikan, nampaknya beberapa siswa sudah mulai bisa mengemukakan pendapatnya atas inisiatif dirinya sendiri, namun masih ada pula siswa yang mengemukakan pendapatnya karena sebatas dorongan dari temannya yang lain, belum ada inisiatif dari diri sendiri.
Selanjutnya pada tahap mengomentari atau berpendapat atas jawaban yang telah diberikan, sudah mulai muncul siswa yang memberanikan diri untuk mengomnetari jawaban yang diberikan. Maka dari itu, peneliti menyimpulkan bahwa rasa ingin tahu siswa dalam pembelajaran sejarah sudah cukup baik. Refleksi yang didapatkan dalam pelaksanaan Siklus IV adalahsiswa sudah mulai tertib saat presentasi berlangsung, mereka menunjukan wajah dan gesture yang serius saat menyimak, siswa mulai banyak yang berani dalam mengajukan pertanyaan, begitu pula dalam hal menjawab dan mengomentari pertanyaan, siswa mulai bisa menginterpretasikan gambar pada puzzle dengan tepat dan dalam waktu yang telah ditentukan, dan guru sudah bisa mengatur waktu yang tersedia dan juga sudah bisa mengkondisikan kelas yang ribut selama kegiatan KBM berlangsung.

Untuk lebih jelasnya, peneliti menggambarkan perolehan kenaikan karakter rasa ingin tahu dalam pembelajaran sejarah melalui media puzzle dari Siklus I-IV dalam bentuk grafik. 
Gambar 4.11

Grafik Pencapaian Skor Rata-rata Perolehan Skor

Karakter Rasa Ingin Tahu Siswa dalam Pembelajaran Sejarah

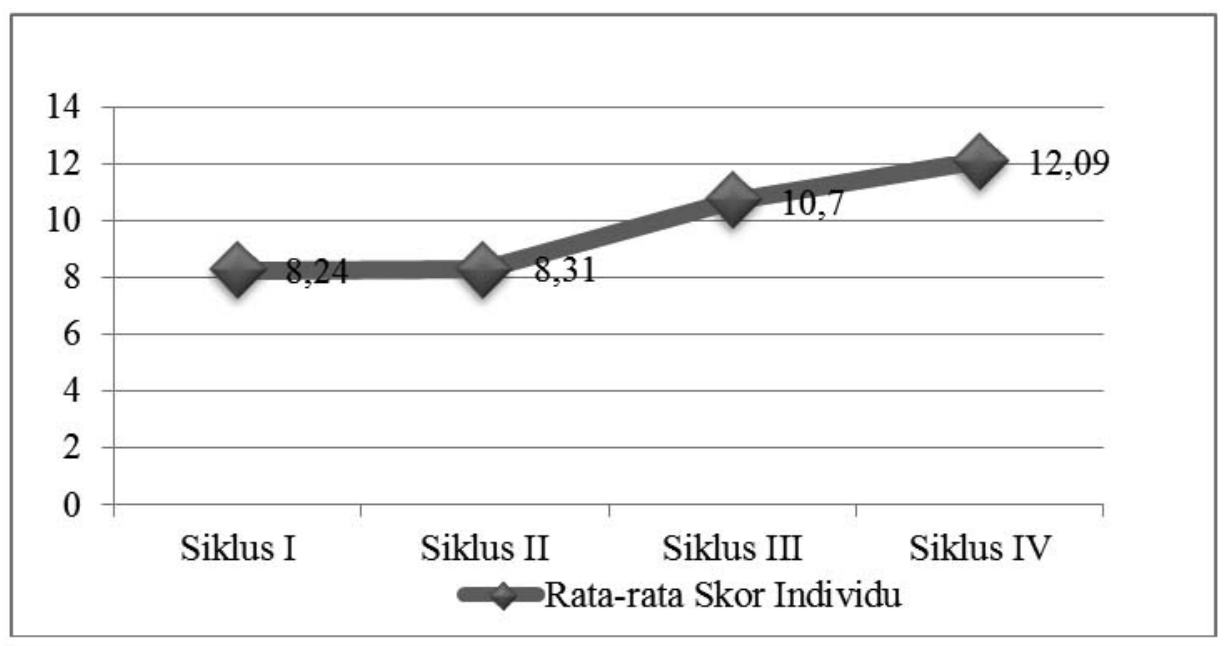

Grafik di atas dibuat berdasarkan data rata-rata perolehan skor individu siswa di setiap siklusnya. Grafik tersebut menunjukan bahwa karakter rasa ingin tahu siswa dalam pembelajaran sejarah melalui penerapan media pembelajaran puzzle mengalami peningkatan. Pada Siklus I skor rata-ratanya mencapai 8,24, Siklus II skor rata-ratanya 8,31, Siklus III skor rata-ratanya adalah 10,7 dan pada Siklus IV memperoleh skor rata-rata 12,09. Pada setiap siklus, terlihat karakter rasa ingin tahu siswa cenderung mengalami kenaikan. Kenaikan ini terjadi selain dikarenakan adanya berbagai perbaikan pada pelaksanaan setiap siklus, kenaikan ini pun menunjukan adanya respon dari siswa terhadap performance dalam pembelajaran sejarah.

\section{SIMPULAN}

Kesimpulan yang didapatkan dari penelitian ini adalah sebelum penelitian dilaksanakan, siswa sudah memiliki potensi karakter rasa ingin tahu namunmasihkurangdioptimalkan. Pada proses selanjutnya perlu dikembangkan karakter rasa ingintahuinidalam pembelajaran sejarah. Namun, setelah diterapkannya media puzzle karakter rasa ingintahusiswadalam pembelajaran sejarah mengalami peningkatan. Sehingga dapat disimpulkan bahwa penggunaan media puzzle ini dirasa cukup efektif untuk menumbuhkan karakter rasa ingin tahu siswa. Demikian kesimpulan yang dapat peneliti sampaikan berdasarkan penelitian yang telah dilakukan. Peneliti berharap penerapan media puzzle dapat memberikan manfaat dalam menumbuhkan karakter rasa ingin tahu siswa, sekaligus meningkatkan pula mutu pendidikan di Indonesia khususnya dalam pembelajaran sejarah.

\section{DAFTAR PUSTAKA}

Asmani, J. (2010). Buku Panduan Internalisasi Pendidikan Karakter di Sekolah. Yogyakarta: Diva Press. 
Das Salirawati. Percaya Diri, Keingintahuan, Berjiwa Wirausaha: Tiga Karakter Penting Bagi Peserta Didik. Jurnal Pendidikan Karakter, Tahun II, Nomor 2, Juni 2012.

Hasan, S.H. (2008). Pengembangan Kompetensi Berpikir Kritis dalam Mata Pelajaran Sejarah. Makalah Seminar IKAHIMSI: Universitas Pendidikan Indonesia.

http://duniaanakcerdas.com/puzzle-2. html, [online] tgl 4 April 2016.

Indriana, Dina. (2011). Ragam Alat Bantu Media Pengajaran. Yogyakarta: Diva Press.

Kesuma, D dkk. (2011). Pendidikan Karakter. Bandung: Rosdakarya.

Narwanti, S. (2011) Pendidikan Karakter. Yogyakarta: Familia.
Sahlan, Asmaun dan Angga Teguh Prastyo. (2012). Desain Pembelajaran Berbasis Pendidikan Karakter. Yogyakarta: ArRuzz Media.

Samani, M dan Haryanto. (2012). Konsep dan Model Pendidikan Karakter. Bandung: Remaja Rosda Karya.

Susilana, Rudi \& Cepi Riyana. (2008). Media Pembelajaran. Bandung: Jurusan Kurikulum dan Teknologi Pendidikan FIP UPI.

Wibawa, B., Mukti, F. (1992). Media Pengajaran. Jakarta: Depdikbud.

Wiriaatmadja, R.(2014). Metode Penelitian Tindakan Kelas untuk Meningkatkan Kinerja Guru dan Dosen. Bandung: PT Remaja Rosdakarya. 